\title{
Pengaruh Wet Cupping terhadap Peningkatan Kadar Hemoglobin
}

\author{
Ibrahim Edy Sapada ${ }^{1}$, Wita Asmalinda ${ }^{2}$ \\ ${ }^{1}$ STIK Siti Khadijah, Palembang, Indonesia \\ ${ }^{2}$ Jurusan Kebidanan, Politeknik Kesehatan Kemenkes Palembang, Indonesia \\ Email: wita_asmalinda@yahoo.co.id
}

\begin{abstract}
The Effect of Wet Cupping on Increased Haemoglobin Level. Efforts to increase hemoglobin are by exercise and physical activity, nutritions food, and wet cupping. Some mechanisms that are thought to underlie the work pathophysiology of Wet cupping include Wet cupping which has the main effect through the pathways of the regulatory system of coagulation such as decreasing blood elements, increasing blood flow and organ oxygenation. The aims of this research to know the effect of Wet cupping on increased hemoglobin level. This study was an experimental clinical trial with the comparison (pretest and posttest with control group design). The research is done at the Clinical Cupping Ibnu Sina Palembang for 30 days. The sample in this study were some adult women who meet the criteria of inclusion and exclusion. A sample size of 52 poeple. Measurement parameter had an increase of hemoglobin. which included a homogeneity test sample using Kolmogorov-simov test, description analysis to know to mean value and standard deviation. There were significantly increased in the number of hemoglobin. Wet cupping affects the increase in hemoglobin levels.
\end{abstract}

Keywords: Hemoglobin, Wet cupping

\begin{abstract}
Abstrak: Pengaruh Wet Cupping terhadap Peningkatan Kadar Hemoglobin. Upaya untuk meningkatkan hemoglobin adalah dengan latihan dan aktivitas fisik, makanan bergizi dan wet cupping. Beberapa mekanisme yang diduga mendasari patofisiologi kerja wet Cupping antara lain, wet Cupping memberikan efek utama melalui jalur sistem regulasi koagulasi-antikoagulasi seperti penurunan elemen darah, peningkatan aliran darah dan oksigenasi organ. Tujuan penelitian ini adalah untuk mengetahui pengaruh wet cupping terhadap peningkatan kadar hemoglobin. Jenis Penelitan ini bersifat eksperimental uji klinis dengan kelompok pembanding (pre-test and post-test with control group design). Penelitian ini dilaksanakan di Klinik Bekam Ibnu Sina Palembang selama 30 hari. Sampel dalam penelitian ini adalah wanita dewasa yang memenuhi kriteria inklusi dan ekslusi. Jumlah sampel adalah 52 responden. Parameter keberhasilan adalah meningkatnya kadar hemoglobin. Data karakteristik sampel dan hasil pengukuran dinilai homogenitasnya dengan menggunakan Uji Kolmogorov-Simov. Analisis deskripsi untuk mengetahui rerata dan standar deviasi. Terjadi peningkatan yang signifikan nilai rerata hemoglobin. Wet cupping berpengaruh terhadap peningkatan kadar hemoglobin.
\end{abstract}

Kata kunci: Hemoglobin, Wet cupping

\section{PENDAHULUAN}

Daya tahan diartikan sebagai kemampuan tubuh untuk melakukan kegiatan atau pekerjaan dalam waktu lama tanpa mengalami kelelahan yang berarti, kemampuan bertahan terhadap semua pengaruh dari luar yang bisa merugikan, seperti penyakit, perubahan cuaca dan iklim dan lain sebagainya (Nurfazlina, 2016). Faktor kelelahan salah satunya adalah kemampuan otot darah untuk mensuplei oksigen (Zufrianingrum, 2016). Untuk pengangkutan oksigen dalam darah membutuhkan hemoglobin. Kadar hemoglobin yang cenderung normal akan memungkinkan seseorang mempunyai ketahanan dalam konsentrasi dan daya tahan kardiorespirasi yang baik sehingga aktifitas dapat berlangsung lama (Zulrianingrum, 2016). Upaya untuk meningkatkan hemoglobin adalah dengan latihan dan aktifitas fisik teratur, konsumsi makanan bergizi (Nurfazlina, 2016; DA Saputro, 2015) dan bekam/wet cupping (Rahmadi, A, 2018). Mekanisme yang diduga mendasari patofisiologi kerja wet cupping terhadap peningkatan kadar hemoglobin adalah memberikan efek utama melalui jalur sistem regulasi koagulasi-anti koagulasi seperti penurunan elemen darah, peningkatan aliran darah dan oksigenasi organ (Ahmadia et al, 2009). 
Wet cupping bagi umat islam adalah pengobatan yang sangat penting, karena merupakan sunnah dari Nabi Muhammad SAW sesuai dengan hadits diantaranya "Sebaik-baik pengobatan yang kalian gunakan adalah bekam" (HR. Muslim) (Rahmadi A, 2018). Wet cupping adalah pengobatan menggunakan sarana gelas atau tabung kaca yang prosesnya diawali dengan melakukan vakum yang bertujuan untuk membuat tekanan negatif sehingga menimbulkan bendungan lokal di permukaan kulit, dilanjutkan dengan perlukaan menggunakan lancet atau pisau bedah terakhir dilakukan vakum lagi (blood letting) di permukaan kulit untuk mengeluarkan darah dan ditampung di gelas atau tabung kaca (Hennawy 2004; El Sayed, 2013).

Proses pertama yang dilakukan pada wet cupping bertujuan untuk membuat bendungan lokal pada permukaan kulit, sehingga menyebabkan hypoxia (penurunan oksigenisasi) ke jaringan kulit (El Sayed, 2013). Respon sel terhadap kondisi hypoksia adalah peningkatan kadar protein Hypoxia inducible factor-1 $\alpha$ (HIF1a) yang merupakan faktor transkripsi memegang peranan penting dalam menjaga keseimbangan oksigen pada tingkat seluler maupun sistem (Winandi, 2009). HIF-1 $\alpha$ ini mengaktivasi sumsum tulang untuk mensekresi sel stem hematopoitik sehingga akan mempercepat produksi eritropoiesis (Guyton and Hall, 2012). Kondisi hypoxia ini juga akan menstimulasi ginjal untuk mempercepat produksi sel darah merah (eritropoiesis) (Guyton and Hall, 2012).

Proses inflamasi lokal, penyayatan dan blood letting yang dilakukan pada wet cupping dianggap sebagai exposure stressor yang akan membahayakan jaringan tubuh sehingga akan menyebabkan stress fisik (Kadir, 2010), Reaksi umum/ general adaptation syndrome terhadap stress fisik adalah memacu serangkaian reaksi dari system Hypothalamus-pituitary-cotex adrenal (HPA) yang menghasilkan adrenocorticotropin hormone dan kortisol (kortikosteroid) yang mengaktivasi sistem saraf simpatik untuk mensekresi epinefrin, norepinefrin dan dopamine (Nugroho, 2011). Hormon-hormon ini akan mengaktivasi ginjal untuk membentuk sel darah yang baru (eritropoiesis) (Guyton and Hall, 2012).

Produksi eritropoiesis ini akan mulai dibentuk dalam beberapa menit dan produksi mencapai puncaknya dalam 24 jam (Guyton and Hall, 2012; Ganong, 2009; Sherwood L, 2014). Rumusan masalah dalam penelitian ini adalah apakah ada perbedaan kadar hemoglobin pada kelompok yang diberikan terapi wet cupping dengan kelompok kontrol yang tidak berikan terapi wet cupping. Tujuan penelitian ini adalah untuk mengetahui pengaruh wet cupping terhadap peningkatan kadar hemoglobin. Manfaat penelitian adalah hasil penelitian ini nantinya dapat dipergunakan sebagai dasar penelitian lanjutan (evidence based) sehingga wet cupping dapat dikembangkan sebagai upaya pengobatan untuk meningkatkan kadar hemoglobin.

\section{METODE}

Jenis Penelitan ini bersifat eksperimental uji klinis dengan kelompok pembanding (pre test and post test with control group design). Penelitian ini dilaksanakan di Klinik Bekam Ibnu Sina Palembang selama 30 hari. Sampel dalam penelitian ini adalah wanita dewasa yang memenuhi kriteria inklusi dan eksklusi. Jumlah sampel sebanyak 52 orang, pengambilan sampel dilakukan secara acak sederhana (simple random sampling). Untuk menentukan sampel masuk dalam kelompok perlakuan atau kelompok kontrol adalah dengan memberikan huruf $\mathrm{A}$ dan huruf B, sampel yang memperoleh huruf A dimasukkan dalam kelompok perlakuan dan sampel yang mendapat huruf B masuk dalam kelompok kontrol (tidak diberikan perlakuan). Kepada semua sampel dijelaskan tujuan, prosedur, manfaat serta resiko sebagai sampel dalam penelitian ini. Setelah mendapatkan persetujuan sampel kemudian menanda tangani Informed consent menjadi responden dalam penelitian ini. Variabel penelitian ini adalah variabel bebas (independen) wet cupping dan variabel terikat (dependen) kadar hemoglobin. Pengambilan darah vena dan pemeriksaan hemoglobin dilakukan oleh petugas kesehatan dari Balai Besar Laboratorium Kesehatan (BBLK) Daerah Sumatera Selatan. Terapi wet cupping dilaksanakan oleh terapis Klinik Bekam Ibnu Sina yang terlatih dan telah tersertifikasi sebagai terapis bekam dari Perkumpulan Bekam Indonesia (PBI). Peralatan yang digunakan untuk wet cupping adalah menggunakan peralatan bekam SOP PBI antara lain; tabung kop/ gelas cupping dan handpump (pompa bekam), lancing device, lancet (jarum steril), nampan/ baskom stainless, mangkok oval/ nierbekken, mangkok kecil steinless pisau bedah, scapel (gagang pisau bedah), gunting, apron, penjepit kasa (klem pean). kain duk, sarung tangan, masker wajah, mangkok/ cawan, kasa steril, kapas, tempat sampah, meja, kursi dan bed periksa. Jika memungkinkan diusahakan memiliki tabung oksigen untuk mengantisipasi apabila terjadi 
pingsan. Bahan yang digunakan adalah: betadine (iodine), alkohol $70 \%$, larutan $\mathrm{H}_{2} \mathrm{O}_{2}$, minyak zaitun dan minyak habatussauda dan Sterilisator (Sarkosih, 2012; Fatahillah, 2019).

Tidak ada persiapan khusus dalam melakukan terapi wet cupping. Klien disarankan makan terlebih dahulu 2 jam sebelum dilakukan wet cupping untuk menghindari pingsan. Dilakukan pemeriksaan umum meliputi: tekanan darah, nadi, temperatur dan pernapasan. Menentukan titik cupping berdasarkan titik sunah. Melakukan pemijatan/urut seluruh tubuh dengan minyak habbatussauda atau minyak zaitun selama 5-10 menit. Vakum/hisap dengan gelas/cup pada kulit di titik-titik wet cupping, dipompa 3-5 kali. Biarkan selama 2-3 menit. Melepaskan gelas cupping, desinfeksi kulit menggunakan betadine/ minyak zaitun, melakukan penusukan dengan lancet, 15-20 tusukan, lalu hisap/ vakum dengan cupping set dan handpump. Dapat diulangi sebanyak 2-3 kali (disesuaikan dengan ketahanan tubuh pasien) dan dibiarkan selama 5-10 menit. Membuka gelas cupping dan membersihkan darah menggunakan kasa steril. Setelah selesai daerah bekam/wet cupping diberikan antiseptik, untuk pencegahan infeksi.

Penelitian ini telah mendapatkan rekomendasi persetujuan etik dari Komisi Etik Penelitian Politeknik Kesehatan Makassar No.476/KEPK-PTKMKS/VI/2019.

\section{HASIL}

Telah dilakukan penelitian eksperimen uji klinis, pengaruh wet cupping terhadap peningkatan kadar hemoglobin dengan rancangan pre dan post test dengan kelompok pembanding (pre-test and post-test with control group design). penelitian ini dilakukan selama 30 hari. Hasil yang diperoleh merupakan data sebelum dan 24 jam setelah dilakukan terapi wet cupping.

Data yang diperoleh dalam penelitian ini kemudian dianalisis secara statistik yang meliputi uji homogenitas sampel menggunakan uji Kolmogorov-Simov, analisis deskriptif untuk mengetahui rerata dan standar deviasi. Data yang dihasilkan terdistribusi secara homogen.

Tabel 1. Karakteristik Responden

\begin{tabular}{lrrrrrc}
\hline Variabel & n & Min & Maks & Mean & Median & SD \\
\hline $\begin{array}{l}\text { Umur } \\
\text { (tahun) }\end{array}$ & 52 & 17 & 35 & 20.88 & 19.00 & 5.128 \\
$\begin{array}{l}\text { Berat } \\
\text { Badan } \\
(\mathrm{kg})\end{array}$ & 52 & 39 & 75 & 52.44 & 50.00 & 8.855 \\
\hline
\end{tabular}

Dari Tabel 1 menunjukkan bahwa dari 52 sampel didapatkan kisaran umur responden terendah adalah 17 tahun dan tertinggi adalah 35 tahun. Umur rerata responden adalah 20.88, dari 52 sampel didapatkan kisaran berat badan responden terendah adalah $39 \mathrm{~kg}$ dan tertinggi adalah $75 \mathrm{~kg}$. Rerata berat badan responden adalah 52.44

\begin{tabular}{|c|c|c|c|c|}
\hline $\begin{array}{l}\text { Sebe } \\
\text { (Kel }\end{array}$ & & $\begin{array}{l}\text { n Sesu } \\
\text { Perlaku }\end{array}$ & & \\
\hline Variabel & $\mathrm{n}$ & $\begin{array}{c}\text { Rerata } \pm \\
\text { SD }\end{array}$ & $\begin{array}{l}\text { Min- } \\
\text { Maks }\end{array}$ & $\begin{array}{c}p \\
\text { value }\end{array}$ \\
\hline $\begin{array}{l}\text { Hemoglobin pre } \\
(\mathrm{gram} / \mathrm{dl})\end{array}$ & 26 & $\begin{array}{r}13.588 \pm \\
1.2144\end{array}$ & $\begin{array}{r}12.00- \\
17.00\end{array}$ & \\
\hline $\begin{array}{l}\text { Hemoglobin } \\
\text { post }(\mathrm{gram} / \mathrm{dl})\end{array}$ & 26 & $\begin{array}{r}13.854 \pm \\
0.9339\end{array}$ & $\begin{array}{r}12.70- \\
15.70\end{array}$ & 0.000 \\
\hline
\end{tabular}

Dari Tabel 2 menunjukkan bahwa nilai rerata hemoglobin sebelum perlakuan adalah $13.588 \pm 1.2144$, sedangkan sesudah perlakuan sebesar $13.854 \pm 0.9339$ dengan selisih rerata adalah sebesar 0.266. Hasil uji statistik menggunakan uji Paired t-test didapatkan nilai $p=0.000$ dengan nilai $\alpha=0.05(p<\alpha)$. Ho ditolak artinya ada perbedaan yang bermakna nilai rerata kadar hemoglobin sebelum dan sesudah pada perlakuan wet cupping.

Tabel 3. Perbedaan Nilai Rerata Hemoglobin sebelum dan sesudah Wet cupping (Kelompok Kontrol)

\begin{tabular}{|c|c|c|c|c|}
\hline Variabel & $\mathbf{n}$ & $\begin{array}{c}\text { Rerata } \pm \\
\text { SD }\end{array}$ & $\begin{array}{l}\text { Min- } \\
\text { Maks }\end{array}$ & $\begin{array}{c}p \\
\text { value }\end{array}$ \\
\hline $\begin{array}{l}\text { Hemoglobin pre } \\
\text { (gram/dl) }\end{array}$ & 26 & $\begin{array}{r}12.450 \pm \\
0.9676\end{array}$ & $\begin{array}{r}10.20- \\
14.80\end{array}$ & \multirow[b]{2}{*}{0.307} \\
\hline $\begin{array}{l}\text { Hemoglobin } \\
\text { post }(\mathrm{gram} / \mathrm{dl})\end{array}$ & 26 & $\begin{array}{r}12.612 \pm \\
1.1120\end{array}$ & $\begin{array}{r}17.00- \\
15.50\end{array}$ & \\
\hline
\end{tabular}

Dari Tabel 3 menunjukkan bahwa nilai rerata hemoglobin pre kelompok kontrol adalah $12.450 \pm 0.9676$, sedangkan nilai rerata hemoglobin post adalah sebesar $12.612 \pm 1.1120$ dengan selisih rerata adalah sebesar $0.16 \overline{2}$. Hasil uji statistik menggunakan uji Paired t-test didapatkan nilai $p=0.307$ dengan nilai $\alpha=0.05$ $(p>\alpha)$. Ho gagal ditolak artinya tidak ada perbedaan yang bermakna nilai rerata kadar hemoglobin pre dan post pada kelompok kontrol. 
Tabel 4. Perbedaan Nilai Rerata Hemoglobin Kelompok Perlakuan Wet cupping dengan Kelompok Kontrol (Independent samples t-test)

\begin{tabular}{|c|c|c|c|c|}
\hline Variabel & $\mathbf{n}$ & $\begin{array}{c}\text { Rerata } \pm \\
\text { SD }\end{array}$ & $\begin{array}{l}\text { Min- } \\
\text { Maks }\end{array}$ & $\begin{array}{c}p- \\
\text { value }\end{array}$ \\
\hline $\begin{array}{l}\text { Hemoglobin } \\
\text { post } 1 \text { (gram/dl) }\end{array}$ & 26 & $\begin{array}{r}13.854 \pm \\
0.9339\end{array}$ & $\begin{array}{r}12.70- \\
15.70\end{array}$ & \multirow{2}{*}{0.000} \\
\hline $\begin{array}{l}\text { Hemoglobin } \\
\text { post } 2 \text { (gram/dl) }\end{array}$ & 26 & $\begin{array}{r}12.612 \pm \\
1.1120\end{array}$ & $\begin{array}{r}10.40- \\
15.50\end{array}$ & \\
\hline
\end{tabular}

Dari Tabel 4 menunjukkan bahwa nilai rerata hemoglobin post kelompok perlakuan wet cupping adalah $13.854 \pm 0.9339$, sedangkan nilai rerata hemoglobin post kelompok kontrol adalah sebesar $12.612 \pm 1.1120$ dengan selisih rerata adalah sebesar 1.242. Hasil uji statistik menggunakan uji Independen t-test didapatkan nilai $p=0.000$ dengan nilai $\alpha=0.05(p<\alpha)$. Ho ditolak, hal ini menunjukkan ada perbedaan yang bermakna nilai rerata hemoglobin post pada kelompok perlakuan wet cupping dengan kelompok kontrol.

\section{PEMBAHASAN}

\section{Efek Wet Cupping terhadap Peningkatan Kadar Hemoglobin}

Dari hasil statistik terhadap jumlah hemoglobin pada kelompok perlakuan wet cupping mengalami peningkatan yang bermakna. Hasil penelitian ini sejalan dengan hasil penelitian Bilal (2011) dan Abdulsattar et al (2014), terjadi peningkatan yang bermakna terhadap jumlah hemoglobin. Hasil penelitian Khalil (2013) terjadi peningkatan jumlah hemoglobin setelah satu minggu wet cupping. Sedangkan penelitian Mahdavi (2013) terjadi peningkatan kadar hemoglobin setelah 2 minggu perlakuan, namun tidak signifikan. Menurut Sharaf (2012) wet cupping berperan mengatur sirkulasi darah di dalam tubuh melalui zat nitrit oksida (NO) yang berperan mendilatasi pembuluh darah. Wet cupping berperan mengurangi darah dan cairan yang menyertai proses peradangan dengan cara mengeluarkan cairan-cairan ini dari celah-celah antar sel. (Sharaf, 2012).

Metode Cupping ini merupakan metode pengeluaran darah statis atau darah kotor, yang dapat membahayakan tubuh jika tidak dikeluarkan. (Sharaf, 2012). Efek wet cupping tidak terbatas pada pembersihan darah mengendap (stagnant blood) dari kulit, namun juga menghilangkan zat-zat berbahaya yang mengendap di bawah kulit (Sharaf, 2012).

Menurut Hennawy (2004) apabila dilakukan wet cupping pada satu titik (poin) maka kulit (kutis), subkutis, fascia dan di otot akan terjadi kerusakan pada sel mast/ basofil. Akibat kerusakan ini akan dilepas beberapa zat seperti serotonin, histamin, bradikinin, Slow reacting substance (SRS) dan zat-zat lain. Histamin bertanggung jawab pada perubahan awal yaitu menyebabkan vasodilatasi pada arteriol dan terjadinya peningkatan dilatasi kapiler dan arteriol serta false reacting. Dilatasi kapiler juga terjadi di tempat yang jauh dari tempat wet cupping. Hal ini menyebabkan terjadinya perbaikan micro circulation peredaran darah. Histamin juga akan mensekresi sitokin $T N F-\alpha$ yang akan mengaktivasi sumsum tulang untuk meningkatkan eritropoiesis. Yang terpenting adalah dilepaskannya corticotropin realising hormon $(C R F)$ yang selanjutnya akan mensekresi ACTH, korticotropin dan kortisol yang akan menyembuhkan peradangan dan menstabilkan permeabilitas sel.

Tekanan negatif pada permukaan kulit pada pengobatan wet cupping menyebabkan reaksi inflamasi atau pembengkakan yang merupakan reaksi cepat terhadap kerusakan jaringan. Inflamasi sangat berguna bagi pertahanan tubuh, sebab reaksi inflamasi tersebut dapat mencegah kerusakan ke jaringan sekitarnya dan mempercepat proses penyembuhan (Widada, 2011).

Peningkatan kadar hemoglobin diduga karena mekanisme wet cupping memberikan efek penurunan konsentrasi oksigen (hypoxia) pada ginjal. (El Sayed, 2013). Salah satu respon sel terhadap kondisi hypoxia adalah peningkatan kadar Hypoxia inducible factors-1 $\alpha(H I F-1 \alpha)$. $H I F-1 \quad \alpha$ adalah faktor transkripsi yang memegang peranan penting dalam menjaga keseimbangan oksigen pada tingkat seluler maupun tingkat molekuler (Winandi, 2009). Penurunan penyaluran oksigen ke ginjal (EPO) akan memicu transkripsi gen eritropoietin yang merangsang ginjal mengeluarkan hormon eritropoitin ke dalam darah dan hormon ini pada gilirannya akan mengaktivasi sumsum tulang untuk mensekresi sel stem hematopoietik yang akan menstimulasi sel eritropoitin di ginjal untuk mensekresi hormon eritropoitin yang akan merangsang eritropoisis oleh sumsum merah (Sherwood L, 2014; Guyton and Hall, 2012).

Sintesis hemoglobin dimulai dalam proeritroblas dan berlanjut sampai stadium retikulosit pada pembentukan sel darah merah. Karenanya ketika retikulosit meninggalkan 
sumsum tulang dan masuk ke aliran darah, retikulosit tetap membentuk sejumlah kecil hemoglobin setelah 24 jam dan seterusnya sampai sel tersebut menjadi eritrosit yang matur (Guyton and Hall, 2012). Bila jumlah besi di dalam plasma sangat rendah, maka cadangan feritin di hepatosit hati, dan sel retikuloendotelial sumsum tulang dengan mudah diangkut dalam bentuk transferin di dalam plasma ke area tubuh yang membutuhkan. Karakter unik dari molekul transferin adalah bahwa molekul ini berikat erat dengan reseptor pada membrane sel eritroblas di sumsum tulang. Selanjutnya dengan besi yang terikat, tranferin masuk ke dalam eritroblas dengan cara endositosis. Di dalam eritroblas, tranferin melepaskan besi secara langsung ke mitokondria tempat heme disintesis (Guyton and Hall, 2012).

Peningkatan kadar hemoglobin dalam penelitian ini juga diduga karena sumsum tulang yang menyimpan cadangan eritropoitin tersebut teraktivasi karena rangsangan dari epinefrin, noreponefrin dan dopamin yang disekresi oleh kelenjar adrenalin dari serangkaian reaksi system hiphotalamus- pituitary- sympathetic- adrenomedulla (SAM) dan sistem hypothalamuspituitary-cortex adrenal (HPA) sehingga sumsum tulang akan merilis deposit eritropoitin ke sirkulasi darah (Kadir, 2010).

Tindakan perlukaan (injury) menggunakan lancet dilanjutkan dengan pengkopan (blood letting) yang bertujuan untuk mengeluarkan darah kotor merupakan rangsangan dari luar tubuh (exposure stessor) yang dapat menyebabkan stres fisik. Jika tubuh bertemu dengan stressor, tubuh akan mengaktifkan sistem saraf dan hormon untuk melaksanakan tindakantindakan pertahanan untuk mengatasi keadaan darurat (Kadir, 2010). Respon saraf utama terhadap rangsangan stres adalah pengaktifan menyeluruh sistem saraf simpatis. Hal ini menyebabkan peningkatan tekanan darah, peningkatan aliran darah ke otak, peningkatan kecepatan metabolisme sel, peningkatan konsentrasi glukosa darah, peningkatan glikolisis di hati dan otot, peningkatan kekuatan otot, peningkatan mental dan peningkatan kecepatan koagulasi darah (Guyton and Hall, 2012). Seluruh efek tersebut menyebabkan orang tersebut dapat melaksanakan aktifitas fisik yang jauh lebih besar dibandingkan bila tidak ada efek di atas (Kadir, 2010).
Fenomena yang terjadi pada kadar hemoglobin kelompok perlakuan wet cupping, ada beberapa responden yang kadar hemoglobinnya dibawah $12 \mathrm{gram} / \mathrm{dL}$ terjadi peningkatan hingga 2 gram/dL. Hal ini diduga karena feritin ditempat penyimpanannya dilepas dengan mudah dan diangkut dalam bentuk tranferin di dalam plasma darah ke area tubuh yang membutuhkan. Responden yang kadar hemoglobinnya tinggi di atas $15 \mathrm{gram} / \mathrm{dL}$ mengalami hal sebaliknya, kadar hemoglobinnya turun hingga $1.5 \mathrm{gram} / \mathrm{dL}$. Pada sampel dengan kadar hemoglobin tinggi, diduga kelebihan besi dalam darah di simpan terutama di hepatosit hati dan sedikit di sel retikulosit sumsum tulang dalam bentuk feritin yang disebut besi cadangan. (Guyton and Hall, 2014; Ganong WF, 2009). Peningkatan dan penurunan kadar hemoglobin setelah wet cupping adalah dalam batas normal yang bertujuan untuk mempertahankan homeostasis di dalam tubuh. Pengobatan wet cupping yang dilakukan secara teratur diduga kuat dapat meningkatkan daya tahan tubuh sehingga kesehatan dan kebugaran tetap terjaga (Widada, 2011).

Dalam kondisi daya tahan tubuh menurun yang disebabkan aktifitas fisik yang berlebihan, kurang istirahat, makan makanan yang mengandung pengawet dan pemanis buatan yang terjadi terus menerus dan tidak dapat dihindari maka dapat direkomendasikan untuk pengobatan wet cupping.

\section{SIMPULAN}

Berdasarkan hasil analisis pembahasan, maka dapat disimpulkan bahwa, terjadi peningkatan yang signifikan nilai rerata hemoglobin setelah 24 jam wet cupping dengan nilai $p$-value 0.000 , dengan peningkatan sebesar 0.266. Pada kelompok kontrol terjadi peningkatan nilai rerata hemoglobin post sebesar 0.162 dengan nilai $p$-value $=0.307$, tidak ada perbedaan yang bermakna nilai rerata hemoglobin pada kelompok kontrol. Hasil uji Independent t-test nilai rerata hemoglobin post kelompok perlakuan dan kontrol didapatkan nilai selisih rerata kedua kelompok adalah sebesar 1.242 dengan nilai $p$-value $=0.000$. Disarankan untuk dilakukan penelitian lebih lanjut pada tingkat molekuler terhadap parameter $H I F-1 \alpha$ dan $T N F-\alpha$. 


\section{DAFTAR PUSTAKA}

Abdulsattar, Fatin, Al-kazazz, Sura A and Mohammed K et al. (2014). Study Effect of Wet Cupping on Hematological Parameters and Inflammatory Proteins of Healthy Iraqi Men. American Journal of Phytomedicine and Clinical Therapeutics 2(5), 644-649.

Ahmadia, A., Farhadia, K. and Schwebelb, D.C. (2009). The Effectiveness of Wet Cupping for Nonspesific Low Back Pain in Iran: A Randamized controlled trial. BMC Complementary Therapies and Alternative Medicine 17, 9-15.

Bilal, Rafeeq, Ahmed and Afroz. (2011). Parsial Evaluation of Tecnique Used in Cupping Therapy. Journal of Basic and Applied Sccience 7(1), 65-68.

DA Saputro, dan Junaidi, S. (2015). dan Jumlah Eritrosit. Journal of Sport Science and Fitness 4(3), 32-40.

El Sayed, Mahmoud and Nabo. (2013). Methods of Wet Cupping Therapy (Al-Hijamah): In Light of Modern. Medicine and Prophertic Medicine. Altern Integ Med 2(3), 1-16.

Fatahillah A., Suhardi K., Akbar Z. (2019). Panduan Pengajaran Bekam Perkumpulan Bekam Indonesia. Cetakan ke-5. Bidang Diklat dan Litbang PBI.

Ganong, WF. (2009). Fisiologi Kedokteran Edisi ke-22. EGC: Jakarta.

Guyton and Hall. 2012. Text Book of Physiology Medicine (Eds. 11th). EGC: Jakarta.

Hennawy. (2004). Cupping Therapy and Infertility. Download from. http://www. obgyn. net, on 10 Nopember 2017).

Kadir. (2010). Perubahan Hormon terhadap Stres. Jurnal kesehatan Universitas Wijaya Kusuma 2(1), 32-39.

Khalil, Al-qaoud and Shaqqour. (2013). Investigation of selected Immunocy togenetic Effects of Wet Cupping in Healthy Men. Journal Spatulla DD 3 (2), 51-7.

Mahdavi, Ghazanfari, Aghajani, Danyali and Naseri, et al. 2013. Evaluation of the Effects of Traditional Cupping on The
Biochemical, Hematological and Immunological Factors of Human Venous Blood. Journal Compendium of Essays on Alternative Therapy 7, 68-88.

Nugroho, Pujo and Nurcahyo. (2011). Physiology and Pathophysiology of Axis Hipotalamus-Hipofisis-Adrenal. Journal Anastesiology Indonesia 3(2), 132-143.

Nurfazlina, Afriwardi dan Syah, NA. (2016). Hubungan Kadar Hemoglobin dengan Daya Tahan Kardiovaskuler pada Pegawai Wanita RS Semen Padang. Jurnal Kesehatan Andalas 5(3), 505-510.

Rahmadi, A. (2018). Integrasi Kedokteran Islam dan Kedokteran Modern (Studi bekam terhadap Hemoglobin). (Tesis pada Sekolah Pasca Sarjana. Universitas Islam Negeri Syarif Hidayatullah). Jakarta.

Sarkosih. (2012). Identifikasi Keselamatan Pasien Terapi Bekam di 4 (Empat) Wilayah DKI Jakarta. Tesis pada Fakultas Kesehatan Mayarakat. Universitas Indonesia.

Sherwood L. (2014). Fisiologi Manusia Dari Sel ke Sistem. Edisi 8. EGC: Jakarta.

Sharaf, A.R. (2012). Penyakit dan Terapi bekamnya; Dasar-dasar Ilmiah Terapi Bekam. Terjemahan oleh: Murtadlo, Saptorini (editor) Sukaeta. Thibbia.

Widada. (2011). Pengaruh Bekam terhadap peningkatan Deformitas Eritrosit pada Perokok. Journal Forikes 2(4), 219-223.

Winandi, S,. Dewi, S. dan Paramita. (2009). Ekspresi Relatif mRNA HIF-l $\alpha$ pada Jantung, Otak dan Darah Tikus Sema Induksi Hipoksia Sistemik. Jurnal Makara Sains 13 (2): 185-188.

Zufrianingrum, H. (2016). Hubungan antara Kadar Hemoglobin dan Kapasitas Vital Paru dengan Daya Tahan Kardiorespirasi Siswa yang Mengikuti Ekstrakulikuler Bola basket di SMP Negeri I Jetis kabupaten Bantul. (Tesis. Fakultas Ilmu Keolahragaan, Universitas Negeri Yogyakarta). 